\title{
Differential glycaemic effects of potato, rice and spaghetti in Type 1 (insulin-dependent) diabetic patients at constant insulinaemia
}

\author{
K. Hermansen ${ }^{1}$, O. Rasmussen ${ }^{1}$, J. Arnfred ${ }^{2}$, E. Winther ${ }^{1}$ and O. Schmitz ${ }^{2}$ \\ ${ }^{1}$ First and ${ }^{2}$ Second University Clinics of Internal Medicine, Aarhus Kommunehospital, Aarhus, Denmark
}

\begin{abstract}
Summary. The blood glucose responses to cooked potato, rice and spaghetti were studied in six Type 1 (insulin-dependent) diabetic patients who had attained euglycaemia by the artificial pancreas prior to the meal intake. The amount of potato (raw weight $200 \mathrm{~g}$ ), parboiled rice (raw weight $50 \mathrm{~g}$ ), and spaghetti (raw weight $50 \mathrm{~g}$ ) had approximately identical caloric content (range $203-225 \mathrm{kcal}$ ) and amount of available carbohydrate (range $39.4-43.4 \mathrm{~g}$ ). The postprandial blood glucose response areas after cooked potato and cooked parboiled rice were similar (180 min values: cooked potato: $1190 \pm$ $110 \mathrm{mmol} / 1 \times \mathrm{min}$, cooked rice: $1160 \pm 140 \mathrm{mmol} / 1 \times \min$ and $240 \mathrm{~min}$ values: cooked potato: $1690 \pm 140 \mathrm{mmol} / 1 \times \mathrm{min}$,
\end{abstract}

cooked rice: $1740 \pm 210 \mathrm{mmol} / \mathrm{l} \times \mathrm{min})$. In contrast, the response after cooked spaghetti was slower and less pronounced ( $180 \mathrm{~min}$ value: $830 \pm 80 \mathrm{mmol} / 1 \times \mathrm{min}$ and $240 \mathrm{~min}$ value: $1320 \pm 120 \mathrm{mmol} / 1 \times \mathrm{min}$ ), and was significantly smaller than those of cooked potato (180 min: $2 p<0.01$ and 240 min: $2 p<0.01$ ) as well as cooked rice (180 min: $2 p<0.01$ and 240 min: $2 p<0.02$ ). Our study emphasizes the importance of determining the glycaemic response of foodstuffs under conditions of isoinsulinaemia.

Key words: Type 1 diabetes, blood glucose, artificial pancreas, diet.

\section{Subjects and methods}

mia for diabetic patients [1], it is surprising that until recently there has been sparse systematic investigation on the effects of different carbohydrate sources on blood glucose excursions [2-7]. The influence of different types of complex carbohydrates has mostly been studied in normal subjects and Type 2 (non-insulin-dependent) diabetic patients $[2,3,5,7,8]$. The reason for the relatively few studies in Type 1 (insulin-dependent) diabetic patients may be due to difficulties in obtaining reproducible, near-normal blood glucose levels before meal intake in these patients $[9,10]$. This latter problem can, however, be circumvented by means of the artificial pancreas [11]. Further, in normal subjects and diabetic patients with preserved endogenous insulin production, some of the observed effects on blood glucose may be due to varying responses of insulin stimulatory gut factors, making the results inapplicable to most Type 1 diabetic patients.

The present investigation was performed to study the short-term metabolic effect of exchangeable amounts of potato, rice and spaghetti on blood glucose levels in lean Type 1 diabetic patients who, by means of the artificial pancreas, had obtained near-normal blood glucose levels prior to the meal intake. The amount of food was designed to fit Danish exchange lists and foods were similar in caloric content.

\section{Subjects}

Six Type 1 diabetic patients fully informed of the experimental nature of the investigation were studied. Clinical data are given in Table 1. All patients were free of clinical signs of peripheral neuropathy and had normal serum creatinine levels. Two patients ( $A L$ and $T K$ ) had background retinopathy. The six patients were randomly assigned to the three meal challenges.

\section{Experimental protocol}

Intermediate insulin was withdrawn $48 \mathrm{~h}$ prior to the experiments and the patients were treated with soluble insulin only. The last soluble in-

Table 1. Clinical data for the six Type 1 (insulin-dependent) diabetic patients

\begin{tabular}{lllrll}
\hline Patient & Sex & $\begin{array}{l}\text { Age } \\
\text { (years) }\end{array}$ & BMI & $\begin{array}{l}\text { Duration of } \\
\text { diabetes } \\
\text { (years) }\end{array}$ & $\begin{array}{l}\text { Insulin } \\
\text { requirement } \\
\text { (U/d) }\end{array}$ \\
\hline AL & M & 64 & 22.2 & 25 & 36 \\
JW & M & 21 & 21.3 & 11 & 40 \\
TK & M & 22 & 22.8 & 11 & 40 \\
CJN & M & 30 & 21.8 & 6 & 28 \\
BR & M & 37 & 22.3 & 8 & 54 \\
BJ & M & 42 & 21.4 & 6 & 50 \\
\hline Mean & & 36 & 22.0 & 11 & 41 \\
SD & & 16 & 0.6 & 7 & 9 \\
\hline
\end{tabular}


Table 2. Meal composition ${ }^{2}$

\begin{tabular}{|c|c|c|c|c|c|c|c|c|}
\hline \multirow[t]{2}{*}{ Food } & \multirow{2}{*}{$\begin{array}{l}\text { Weight } \\
\text { (g) }\end{array}$} & \multicolumn{2}{|c|}{ Energy } & \multirow{2}{*}{$\begin{array}{l}\text { Starch } \\
\text { (g) }\end{array}$} & \multirow{2}{*}{$\begin{array}{l}\text { Sugars } \\
\text { (g) }\end{array}$} & \multirow{2}{*}{$\begin{array}{l}\text { Dietary } \\
\text { fibers } \\
\text { (g) }\end{array}$} & \multirow{2}{*}{$\begin{array}{l}\text { Fat } \\
\text { (g) }\end{array}$} & \multirow{2}{*}{$\begin{array}{l}\text { Protein } \\
\text { (g) }\end{array}$} \\
\hline & & (Kcal) & $(\mathrm{Kj})$ & & & & & \\
\hline Rice parboiled, raw & 50 & 181 & 768 & 43.4 & $\operatorname{Tr}$ & 1.2 & 0.5 & 3.3 \\
\hline Spaghetti, white raw & 50 & 189 & 806 & 40.7 & 1.4 & - & 0.5 & 6.8 \\
\hline Potatoes, old raw & 200 & 174 & 744 & 40.6 & 1.0 & 4.2 & 0.2 & 4.2 \\
\hline
\end{tabular}

a In addition, each meal contained $250 \mathrm{ml}$ water

Table 3. Blood glucose response (area above basal) after meals of cooked potato ( $200 \mathrm{~g})$, white rice $(50 \mathrm{~g})$ and white spaghetti $(50 \mathrm{~g})$ given to type 1 diabetic patients

\begin{tabular}{|c|c|c|c|c|c|c|}
\hline \multirow[b]{3}{*}{ Patient } & \multicolumn{3}{|c|}{$\begin{array}{l}\text { Blood glucose response } \\
(180 \mathrm{~min} \text { postprandial period })(\mathrm{mmol} / 1 \times \mathrm{min})\end{array}$} & \multicolumn{3}{|c|}{$\begin{array}{l}\text { Blood glucose response } \\
\text { ( } 240 \mathrm{~min} \text { postprandial period })(\mathrm{mmol} / \mathrm{l} \times \mathrm{min})\end{array}$} \\
\hline & Potato & White rice & White spaghetti & Potato & White rice & $\begin{array}{l}\text { White } \\
\text { spaghetti }\end{array}$ \\
\hline & A & B & $\mathrm{C}$ & A & B & $\hat{C}$ \\
\hline $\mathrm{AL}$ & 780 & 870 & 570 & 1200 & 1360 & 910 \\
\hline SW & 1480 & 1500 & 960 & 2080 & 2330 & 1670 \\
\hline $\mathrm{BR}$ & 1450 & 1620 & 1060 & 2110 & 2410 & 1600 \\
\hline BJ & 1050 & 1160 & 970 & 1490 & 1670 & 1360 \\
\hline Mean & 1190 & 1160 & 830 & 1690 & 1740 & 1320 \\
\hline$\pm \mathrm{SEM}$ & 110 & 140 & 80 & 140 & 210 & 120 \\
\hline
\end{tabular}

A vs. B, NS; A vs. C, $p<0.01$; B vs. C, $p<0.01$;

A vs. B, NS; A vs. C, $p<0.01$; B vs. C, $p<0.02$

sulin was given at $17.00 \mathrm{~h}$ the day before the study. At $22.00 \mathrm{~h}$ the patients were connected to the artificial endocrine pancreas (Biostator, Miles Laboratories, Elkhart, IN, USA) to achieve a normoglycaemic equilibrium. The set constants were $\mathrm{KR}=150, \mathrm{KF}=50, \mathrm{BI}=100$, $\mathrm{QI}=40, \mathrm{RI}=0.15 / \mathrm{kg}$ body weight, $\mathrm{FI}=320, \mathrm{BD}=70, \mathrm{QD}=20$, $\mathrm{RD}=90$ and $\mathrm{FD}=360$. Operating mode $3: 0$, indicating static plus dynamic control of insulin infusion, was used. At $08.00 \mathrm{~h}$ after an overnight fast, the operating mode was changed to 7:0 and the RD to zero in order to maintain a constant insulin infusion rate of $0.15 \mathrm{mU}$ per $\mathrm{kg}$ body weight without glucose infusion.

\section{Meals}

The meal protocol consisted of administering on separate days in random order one of three complex carbohydrate meals containing $50 \mathrm{~g}$ parboiled rice (raw weight), $50 \mathrm{~g}$ white spaghetti made from durum wheat semolina (raw weight) or $200 \mathrm{~g}$ potato (raw weight). The concomitant water intake constituted $250 \mathrm{ml}$. Table 2 gives the approximate carbohydrate, protein, starch, sugar, fibers and energy content in these fixed meals according to Paul and Southgate [15]. As seen in Table 2 , the content of available carbohydrate was approximately $40 \mathrm{~g}$. Potatoes, rice and spaghetti were cooked for 19,12 and $10 \mathrm{~min}$. The meal was eaten between 08.30 and $09.00 \mathrm{~h}$ during a 10 -min period. Blood glucose levels ranging between 4.8 and $7.7 \mathrm{mmol} / 1$ were maintained at this level for at least $1 \mathrm{~h}$ before starting the experiment. The subjects were asked to micturate just before meal intake. The glucose loss was then measured in the urine collected during the test period $(0-240 \mathrm{~min})$. Patients sat in their beds throughout the experiment.

\section{Analytical techniques}

Plasma and urinary glucose were measured by the glucose oxidase method. $\mathrm{HbA}_{1 \mathrm{c}}$ values were determined by a commercial kit (Bio-Rad, Richmond, CA, USA) (normal $\mathrm{HbA}_{1 \mathrm{c}}$ values $3.5-5.5 \%$ ). Serum free insulin levels were determined as described by Nakagawa et al. [16] with modifications [17]. C-peptide was measured by a commercial kit (Immunonuclear Corporation, Stillwater, MN, USA).

\section{Statistical analysis}

Areas under blood glucose curves were calculated geometrically by subtracting the mean basal blood glucose concentration from each value. Results of all measurements are expressed as the mean $\pm S E M$. The significance was calculated using Student's t-test for paired data.

\section{Results}

In all diabetic patients, plasma C-peptide levels were lower than $1.1 \mathrm{ng} / \mathrm{ml}$ in the fasting state without a significant increase after the meals. The postprandial increase in blood glucose after cooked potato, rice and spaghetti is shown in Figure 1. Before the three meals no significant difference was seen in the mean fasting blood glucose values, which were close to normal. Furthermore, similar or identical $\mathrm{HbA}_{1 \mathrm{c}}$ values $(7.3 \pm$ $1.3(\mathrm{SD}) \%$ potato, $7.0 \pm 0.9(\mathrm{SD}) \%$ rice, $7.6 \pm 0.6(\mathrm{SD}) \%$ spaghetti) were also present before potato, rice and spaghetti meals respectively. Following potato and rice similar mean areas of blood glucose above basal values were found after $180 \mathrm{~min}$ and $240 \mathrm{~min}$, being $1190 \pm$ $110 \mathrm{mmol} / 1 \times \mathrm{min}$ and $1160 \pm 140 \mathrm{mmol} / 1 \times \min$ and $1690 \pm 140 \mathrm{mmol} / 1 \times \mathrm{min}$ and $1740 \pm 210 \mathrm{mmol} / 1 \times \mathrm{min}$ respectively (Table 3 ). After ingestion of spaghetti, however, the blood glucose response was considerably slower (Fig. 1) and the mean blood glucose response area was significantly smaller, constituting $830 \pm$ $80 \mathrm{mmol} / 1 \times \mathrm{min}$ after $180 \mathrm{~min}$ and $1320 \pm$ $120 \mathrm{mmol} / 1 \times \mathrm{min}$ after $240 \mathrm{~min}$ (for $p$ values see Table 3). Thus, compared to the potato response, the 
spaghetti blood glucose response area was reduced by $30 \pm 5 \%(2 p<0.01)$ after $180 \mathrm{~min}$ and $22 \pm 3 \%(2 p<$ 0.001 ) after $240 \mathrm{~min}$. When compared to the rice response, the spaghetti blood glucose response area was blunted by $28 \pm 3 \%(2 p<0.001)$ after $180 \mathrm{~min}$ and $23 \pm$ $5 \%(2 p<0.01)$ after $240 \mathrm{~min}$. Although the amount of glucose being lost in the urine appeared slightly higher to potato $(10.9 \pm 3.7 \mathrm{~g})$ and rice $(10.0 \pm 3.6 \mathrm{~g})$ than to spaghetti $(8.0 \pm 3.0 \mathrm{~g})$, this difference did not attain statistical significance. As seen in Table 4, identical average plasma free insulin levels were measured during the test period $(0-240 \mathrm{~min})$ in response to potato $(12.6 \pm$ $1.8 \mu \mathrm{U} / \mathrm{ml})$, rice $(12.3 \pm 1.7 \mu \mathrm{U} / \mathrm{ml})$ and spaghetti $(12.8 \pm 0.9 \mu \mathrm{U} / \mathrm{ml})$.

\section{Discussion}

Traditionally, the dietary treatment of diabetes is based on the idea that foods with similar proportions of carbohydrate, protein and fat produce similar glycaemic responses. A growing body of data, however, shows that chemically similar foods can differ in their impact on blood glucose. Thus, different carbohydrate foods produce different glycaemic responses in normal subjects as well as diabetic patients [2-14, 18-21]. Most of this knowledge was obtained in non-diabetic or Type 2 diabetic individuals $[2-10,12,14,18-20]$. The reason for the relatively scant number of studies testing carbohydrate foods in Type 1 diabetic patients [9-11,13] may be ascribed to difficulties in obtaining similar basal blood glucose levels before the different test meals.

By use of the artificial pancreas, we avoided variation in subcutaneous insulin depot absorption and began the meal administration at reproducible, near-normal blood glucose concentrations. We used the Danish food exchange system to calculate the amounts of potato, rice and spaghetti [22]. The three test meals contained approximately $40 \mathrm{~g}$ available carbohydrate and were approximately isocaloric (Table 3 ).

We found that spaghetti produced a significantly smaller increase in blood glucose in Type 1 diabetic patients than either cooked potato or cooked rice in the period 0-180 and 0-240 min. Despite this observation, we were unable to pick up any significant difference in the amount of glucose being spilled in the urine in response to spaghetti versus potato and rice. This may in part be due to a rather large interindividual variability in the renal threshold in these insulin-dependent diabetic patients. In a heterogenous group of both Type 2 and Type 1 diabetic subjects, Jenkins et al. [18] also found that spaghetti caused a relatively slow and small blood glucose response when comparing with exchangeable amounts of white bread and wholemeal bread. In another mixed group of diabetic patients, Parillo et al. [23] looked at the glycaemic responses to a mixed meal to which either $50 \mathrm{~g}$ carbohydrate portion of either spaghetti or potato was added. They also found that the

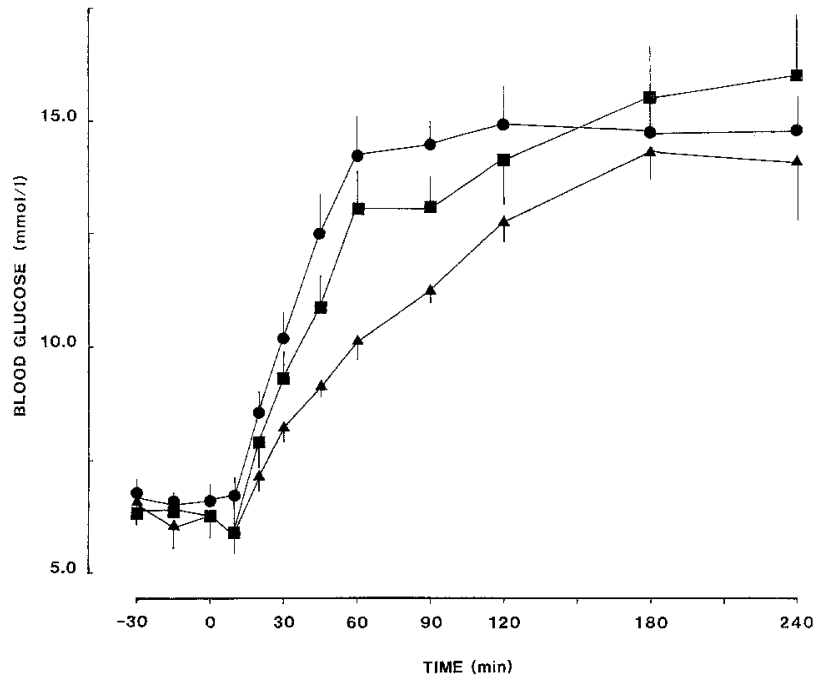

Fig. 1 Mean blood glucose variations observed after cooked potato (raw weight: $200 \mathrm{~g}$ ) (@), white rice (parboiled) (raw weight: $50 \mathrm{~g}$ ) ( $\mathbf{\square}$ ), and spaghetti (raw weight: $50 \mathrm{~g}$ ) ( $\mathbf{\Delta}$ ) in six Type 1 (insulin-dependent) diabetic patients receiving constant insulin infusion by an artificial pancreas. Meal intake took 10 min. Values are mean \pm SEM

Table 4. Mean plasma free insulin $(\mu \mathrm{U} / \mathrm{ml})$ (mean \pm SEM) in 6 Type 1 diabetic patients ingesting cooked potato $(200 \mathrm{~g})$, white rice $(50 \mathrm{~g})$ and white spaghetti $(50 \mathrm{~g})$

\begin{tabular}{llll}
\hline Time (min) & Potato & Rice & Spaghetti \\
\hline-30 & $17.1 \pm 2.1$ & $17.1 \pm 3.1$ & $18.0 \pm 2.9$ \\
-15 & $12.1 \pm 0.9$ & $16.0 \pm 0.8$ & $18.9 \pm 1.4$ \\
0 & $14.8 \pm 2.2$ & $14.5 \pm 1.7$ & $13.0 \pm 0.6$ \\
10 & $14.0 \pm 3.1$ & $11.7 \pm 2.3$ & $12.1 \pm 1.0$ \\
20 & $11.8 \pm 2.4$ & $12.0 \pm 1.6$ & $13.1 \pm 1.6$ \\
30 & $14.0 \pm 1.7$ & $13.0 \pm 2.5$ & $16.5 \pm 0.9$ \\
45 & $13.3 \pm 2.4$ & $12.5 \pm 1.9$ & $13.5 \pm 1.8$ \\
60 & $12.5 \pm 2.2$ & $13.3 \pm 1.6$ & $14.1 \pm 1.3$ \\
90 & $14.0 \pm 1.9$ & $12.5 \pm 1.5$ & $13.0 \pm 0.8$ \\
120 & $11.0 \pm 1.8$ & $13.1 \pm 2.3$ & $12.2 \pm 0.6$ \\
180 & $12.5 \pm 1.5$ & $11.5 \pm 0.9$ & $12.0 \pm 1.8$ \\
240 & $13.6 \pm 1.4$ & $10.7 \pm 1.0$ & $12.3 \pm 0.8$ \\
Average level & $12.6 \pm 1.8$ & $12.3 \pm 1.7$ & $12.8 \pm 0.9$ \\
$0-240$ min & & & \\
\hline
\end{tabular}

glycaemic response was significantly lower after a spaghetti meal than after a potato meal [23]. In none of these experiments were premeal blood glucose levels normalized, which makes strict comparison difficult. Most of their patients had retained insulin production, implying that differences in blood glucose profiles may partly be due to different ability to release insulin stimulatory gut factors. It is likely that different results are obtained in Type 1 diabetic patients without endogenous insulin. The amount of dietary fibers in the test meals seems to play a minor role, since removal of the fibres from rice [20] and spaghetti [18] has no effect on the glycaemic response to these foods. The disparity in results may be ascribed to differences in gastric emptying, differences between the forms of starches and differences in content of antinutrients [24]. The finding of relatively pronounced, and rapid blood glucose excursions after 
ingestion of cooked potato or cooked rice corroborate previous results obtained in Type $2[2,4,13,19]$ and Type $1[4,13]$ diabetic patients. In Type 1 diabetic patients Jenkins et al. [9] found large interindividual variation in the glycaemic responses to a specific test meal. This was, however, not the case in our study. The reason for this discrepancy may be that we have achieved the same, near-normal pretest blood glucose level as well as a constant insulinaemia throughout the experiment by the artificial pancreas. Thus, it is well known that the insulinaemia is extremely important for the postprandial glucose response to carbohydrate [25]. It is likely that great variations in insulin levels within as well as between experiments do exist in diabetic patients treated by conventional, subcutaneously administered insulin [9].

We conclude that the glycaemic response to spaghetti is significantly lower than so-called exchangeable amounts of potato or rice, and that spaghetti appears to be an acceptable alternative as a carbohydrate source. The approach in which the most important variable, i.e. the insulinaemia, was kept constant by the artificial pancreas seems to be a valuable tool for studying glycaemic responses to different carbohydrate meals in Type 1 diabetic patients. It is important to look not only at the glycaemic impact of the different carbohydrate foods since the amounts of fat and protein in the concomitantly ingested meal may profoundly modulate the glycaemic responses of these carbohydrate constituents.

Acknowledgements. We thank the patient volunteers whose collaboration made this study possible, Ms. K. Just, E. Seier and A. Lorenzen for expert technical assistance and Ms. A. Larsen for typing the manuscript. This work was supported by grant from the Danish Diabetes Association, The Nordic Insulin Foundation, P. Carl Petersens Foundation and Fonden til Lægevidenskabens Fremme.

\section{References}

1. Unger RH (1983) Meticulous control of diabetes: Benefits, risks, and precautions. Diabetes 31:479-483

2. Crapo PA, Insel J, Sperling M, Kolterman OG (1981) Comparison of serum glucose, insulin, and glucagon responses to different types of complex carbohydrate in non-insulin-dependent diabetic patients. Am J Clin Nutr 34: 184-190

3. Jenkins DJA, Wolever TMS, Thorne MJ, Jenkins AL, Wong GS, Josse RG, Csima A (1984) The relationship between glycemic response, digestibility, and factors influencing the dietary habits of diabetics. Am J Clin Nutr 40: 1175-1191

4. Bantle JP, Laine DC, Castly GW, Thomas JW, Hoogwerf BJ, Goetz FC (1983) Postprandial glucose and insulin responses to meals containing different carbohydrates in normal and diabetic subjects. N Engl J Med 309: 7-12

5. Coulston A, Greenfield MS, Kraemer FB, Tobey TA, Reaven GM (1981) Effect of differences in source of dietary carbohydrate on plasma glucose and insulin responses to meals in patients with impaired carbohydrate tolerance. Am J Clin Nutr 34: 2716-2720

6. Jenkins DJA, Wolever TMS, Jenkins AL, Josse RG, Wong GS (1984) The glycaemic response to carbohydrate foods. Lancet II: 388-391

7. Conn JW, Newburgh LH (1936) The glycemic response to isoglucogenic quantities of protein and carbohydrate. J Clin Invest 15: $665-671$
8. Hagander B, Björck I, Asp N-G, Lundquist I, Nilsson-Ehle P, Schrezenmeir J, Schersten B (1985) Hormonal and metabolic responses to breakfast meals in NIDDM: Comparison of white and whole-grain wheat bread and corresponding extruded products. Human Nutr: Appl Nutr 39 A: 114-123

9. Jenkins DJA, Wolever TMS, Wong GS, Kenshole A, Josse RG, Thompson LV, Lam KY (1984) Glycemic responses to foods: possible differences between insulin-dependent and non-insulin-dependent diabetics. Am J Clin Nutr 40: 971-981

10. Heinonen L, Korpila R, Mantere S (1985) The effect of different types of finnish bread on postprandial glucose response in diabetic patients. Human Nutr: Appl Nutr 39 A: 108-113

11. Slama G, Klein J-C, Delage A, Ardila E, Lemargnen H, Papoz L, Tchobroutsky G (1981) Correlation between the nature and amount of carbohydrate in meal intake and insulin delivery by the artificial pancreas in 24 insulin-dependent diabetics. Diabetes 30: $101-105$

12. Nuttall FQ, Mooradian AD, DeMarais R, Parker S (1983) The glycaemic effect of different meals approximately isocaloric and similar in protein and carbohydrate and fat content as calculated using the ADA exchange tests. Diabetes Care 6:432-435

13. Vaaler S, Hanssen KF, Aagenæs $\varnothing$ (1984) The effect of cooking upon the blood glucose response to ingested carrots and potatoes. Diabetes Care 7: 221-223

14. Coulston A, Greenfield M, Kraemer F, Tobey F, Reaven G (1980) Effect of source of dietary carbohydrate on plasma glucose and insulin responses to test meals in normal subjects. Am J Clin Nutr 33: $1279-1282$

15. Paul AA, Southgate DAT (1978) McCauce and Widowson's the composition of foods, 4th edn. Medical Research Council Special Report Series no. 297. Her Majesty's Stationary Office, London

16. Nakagawa S, Nakagawa H, Sasuki T, Yoshino K, Yu YY, Skinozaki K, Aoki S, Mashimo K (1973) A simple method for the determination of serum insulin levels in insulin-treated patients. Diabetes 22: $590-600$

17. Schmitz O, Alberti KGMM, Ørskov H (1984) Insulin resistance in uraemic insulin-dependent diabetics. Effect of dialysis therapy as assessed by the artificial endocrine pancreas. Acta Endocrinol (Copenh) 105: 371-378

18. Jenkins DJA, Wolever TMS, Jenkins AL, Lee R, Wong GS, Josse R (1983) Glycemic response to wheat products: Reduced response to pasta but no effect of fiber. Diabetes Care 6:155-159

19. Jenkins DJA, Wolever TMS, Taylor $\mathrm{RH}$, Barker $\mathbf{H}$, Fielden $\mathrm{H}$, Baldwin JM, Bowling AC, Newmann HC, Jenkins AL, Goff DV (1981) Glycemic index of foods: a physiological basis for carbohydrate exchange. Am J Clin Nutr 34: 362-366

20. O'Dea, Nestel PJ, Antonoff I (1980) Physical factors influencing postprandial glucose and insulin responses to starch. Am J Clin Nutr 33: 760-765

21. Haber GB, Heaton KW, Murphy D, Burroughs LF (1977) Depletion and disruption of dietary fibre: effects on satiety, plasma-glucose and insulin. Lancet 2: 679-682

22. Kostudvalget, Landsforeningen for Sukkersyge (1982) Vejledning i tilrettelæggelse af diabeteskost, publikation nr.5, OAB-Tryk, Odense

23. Parillo M, Giacco R, Riccardi G, Pacioni D, Rivellese A (1985) Different glycaemic responses to pasta, bread and potatoes in diabetic patients. Diabetic Medicine 2: 374-377

24. Crapo PA, Olefsky JM (1983) Food fallacies and blood sugars. N Engl J Med 309: 44-45

25. Cahill GF (1971) Physiology of insulin in man. Diabetes 20: $785-799$

Received: 20 January 1986

and in revised form: 28 April 1986

Dr. K. Hermansen

Second University Clinic of Internal Medicine

Kommunehospitalet

DK-8000 Aarhus C

Denmark 